\title{
MORPHOLOGY OF UREDINIA AND UREDINIOSPORES OF THE FUNGUS Melampsora larici-epitea KLEB. A DAMAGING PATHOGEN OF COMMON OSIER (Salix viminalis L.) IN POLAND
}

\author{
Joanna Ciszewska-Marciniak ${ }^{1}$, Małgorzata Jędryczka ${ }^{1}$, Stanisław Jeżowski ${ }^{1}$, \\ Jerzy Przyborowski², Katarzyna Wojciechowicz ${ }^{3}$, Elżbieta Zenkteler ${ }^{3}$ \\ ${ }^{1}$ Institute of Plant Genetics, Polish Academy of Sciences, Poznań, Poland \\ ${ }^{2}$ Department of Plant Breeding and Seed Production, University of Warmia and Mazury, Olsztyn, Poland \\ ${ }^{2}$ Department of General Botany, Adam Mickiewicz University, Poznań, Poland \\ e-mail: jcis@igr.poznan.pl
}

Received: 05.08.2010

\section{Abstract}

Rust (Melampsora spp.) is a damaging disease of willows (Salix spp.), including common osier (S. viminalis L.). So far, the pathogens of this species found in Europe were identified as M. larici-epitea Kleb. or M. ribesii-viminalis Kleb. Moreover, a stem infecting form (SIF), deprived of a sexual stage in its life cycle was reported. The aim of this study was to find out which species of the rust fungi cause disease symptoms on common osier in Poland. The isolates from common osier were compared to the ones originating from its putative hybrids with trembling aspen (Populus tremula L.) and Simon's poplar (P. simonii Carr.). Fungal isolates were obtained in 2008-2010 from 15 different genotypes of willows, including seven varieties of common osier (4 Swedish and 3 Polish), two landraces of common osier and six putative hybrids with poplars. Fungal isolates originated from three experiment sites, including west (Wielkopolska and Lubuskie) and north-east (Warmia) regions of Poland. To ensure the genetic uniformity, the isolates were derived from single uredinia, obtained from natural infection conditions. In all collected samples the position of uredinia was always hypophyllous. The diameter of uredinia was measured by Sigma Scan Pro software, after inoculation of four standard genotypes, including two common osier and two willow hybrids.

The studies proved that the main cause of common osier rust is Melampsora larici-epitea f. typica. All studied isolates, including the ones obtained on putative hybrids, were very similar according to the size of uredinia and the size and morphology of urediniospores. The average size of a uredinium was $1.1 \mathrm{~mm}$ diameter and slightly differed between the isolates (from 0.9 to $1.3 \mathrm{~mm}$ ), depending on willow genotype, the quality of plant material used for artificial inoculations and infection conditions. The average size of a typical urediniospore was $12.4 \times 10.5$ $\mu \mathrm{m}$, but the sizes varied from 9.8 to $13.2 \mu \mathrm{m}$. Urediniospores from common osier were slightly bigger and more oval (12.5 x $10.4 \mu \mathrm{m})$ as compared to spores from the putative hybrids Salix x Populus $(12.3 \times 10.6 \mu \mathrm{m})$, but the differences were statistically insignificant. The spores were ovoid, globoid or angular, evenly echinulated. The size of uredinia, as well as the size and morphology of urediniospores were in full agreement with literature data for M. larici-epitea f. typica.

Key words: Melampsora larici-epitea, common osier willow, Salix viminalis, uredinia, urediniospores, willow rust

\section{INTRODUCTION}

The diversity of willows (Salix spp.) worldwide is enormous. According to different sources, the number of willow species varies between 300 and 500, with about 270 willow species in China, 120 in the former Soviet Union, over 100 in North America and some 65 willow species in Europe (Arg u s, 1997; P e i , 2005). Moreover, the genetic diversity within one willow species can be also tremendous. Recent interest in the common osier (Salix viminalis L.), a potential source of biomass production for renewable energy (Ke ole ian and Volk, 2005; S zc zukowski et al. 2005), showed great genetic differences between the genotypes (Przyborowski and Sulima, 2010). The variation was also observed for numerous traits, including disease resistance ( $\mathrm{J}$ ę r y c zka et al. 2008; Rönnberg-Wästljung et al. 2008). Immense diversity present between and within willow species influences its main pathogen - willow rust (Melampsora spp.). This important fungal genus, gathering numerous pathogens of various plant species, coevolves with hosts, what also results in its great diversity (S a vile , 1976; R a m s te d t , 1999; S a mils, 
Joanna Ciszewska-Marciniak, Małgorzata Jędryczka, Stanisław Jeżowski,

Jerzy Przyborowski, Katarzyna Wojciechowicz, Elżbieta Zenkteler

2005). The populations of this pathogen greatly depend on the composition of host-plant populations, in respect to their resistance ( $\mathrm{S}$ a m i l s et al. 2001) as well as crop density and spacious distribution of particular genotypes (McCracken et al. 2001; Samils et al. 2003). The genus Melampsora found on willows is heteroecious, what results in a very complex way of development, including five different spore stages in one life cycle. Some of them form only on specific alternate hosts from different taxonomic groups, usually very distant from Salicaceae family. P e i (2005) listed 33 species of Melampsora found on willows, with additional forms and pathotypes, differing with their host range and infection characteristics. Some 11 of these species occur exclusively on the subgenus Salix.

Willow rusts occurring on common osier are very damaging pathogens, so they were subjected to numerous studies (P a r k e r et al. 1993; P e i et al. 1999; 2004; M c Cracken and Daw s o , 2003). It was found that the most common species originating from $S$. viminalis is $M$. larici-epitea Kleb., whose alternate host is larch (Gäumann, 1959; Pei et al. 1996). Common osier can be also attacked by $M$. ribesii-viminalis Kleb., the species alternating on currant ( $\mathrm{G}$ ä u mann, 1959; Wils on and Henders on, 1966). Moreover, the studies of Pe i et al. (1995) proved the existence of a stem-infecting form (SIF), with no alternate host and no sexual reproduction. By now, this unusual form has been found only on British Isles. It illustrates a fast co-evolution of the pathogen, accompanying the increased cultivation and recent advances in breeding of common osier ( $\mathrm{H} \mathrm{u}$ t e r et al. 2002). The process of evolutionary specialization is common to all rust fungi (L e p pi k, 1972).

By now, there were no thorough studies of willow rust and its causal agent in Poland. The aim of this study was to find out which species of the rust fungi cause disease symptoms on common osier in Poland. The isolates from common osier were compared to the ones originating from its putative hybrids with trembling aspen (Populus tremula L.) and Simon's poplar (P. simonii Carr.).

\section{MATERIALS AND METHODS}

\section{Field experiment sites}

Field experiments were located at three sites, in west and north-east Poland:

1) experiment field of the Institute of Plant Genetics, Polish Academy of Sciences in Poznan, Wielkopolska region, N52²2'52,8'; E16 53'54,1'”

2) Selo Energia Ltd. - agricultural farm in Marzęcin, Lubuskie region, $\mathrm{N} 51^{\circ} 52^{\prime} 00,0^{\prime \prime}$; E15 34'00,0"

3) Didactic and Experimental Station in Bałdy, University of Warmia and Mazury in Olsztyn, Warmia

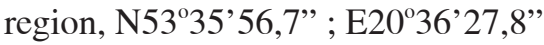

\section{Plant material}

Fungal isolates originated from nine genotypes of common osier (S. viminalis) and its five putative hybrids with trembling aspen $(P$. tremula) and one putative hybrid with Simon's poplar ( $P$. simonii). The detailed description of the methods used to obtain the hybrids was presented elsewhere, by Z e n k te l e r et al. (2005). Two genotypes of common osier were growing at both locations in west Poland, and the hybrids were cultivated in west and north-east Poland (Table 1). The oldest field originated from Marzęcin and it was planted in the spring of 1997, whereas the common osier willow genotypes from Poznan started their growth in the spring of 2002 and these from Bałdy - in the spring of 2006. All hybrids were planted in the autumn of 2007.

\section{Fungal material}

Samples of leaves with the symptoms of willow rust were collected at each time of disease assessment. The leaves were dried for a few days at room temperature. Then, the samples were placed in Kristal semi-transparent glassine smooth bags (Brian Springfield, Bristol, UK) and stored at $-20^{\circ} \mathrm{C}$. The propagation of urediniospores was done using young leaves of a hybrid S. aurita $x$ viminalis $x$ caprea var. Stipularis, grown for 6-8 weeks in glasshouse conditions. Plant material used for the propagation was each time obtained from cuttings originating from the previous season and stored at $+4^{\circ} \mathrm{C}$. Cultivation in a glasshouse was done using 16/8 hour photoperiod, at $18-20^{\circ} \mathrm{C}$ and $16-18^{\circ} \mathrm{C}$, respectively at daytime and night (darkness). Freshly collected young and soft willow leaves were placed in $90 \mathrm{~mm}$ diameter Petrie dishes on discs of filter paper soaked with sterile distilled water. Each leaf was covered with urediniospores originating from one chosen uredinium, obtained from the material collected in field conditions, at particular genotypes, years and experiment sites. The spores were uniformly spread with a brush, previously sterilized in $99,8 \%$ ethanol. Petrie dishes with leaves bearing spores were transferred to controlled environment (CE) chambers (Mytron WB1500, Bio- und Solartechnik $\mathrm{GmbH}$, Heilbad Heiligenstadt, Germany) with $16 / 8$ hour photoperiod, at a constant temperature of $16^{\circ} \mathrm{C}$. Each cycle of propagation of urediniospores lasted 13 days. The second propagation cycle was also started using one selected uredinium, whereas the following cycles used a mixture of all uredinia obtained from the previous propagation. In such way, the finally obtained urediniospores were numerous and they were all genetically identical. The propagation of a sufficient number of spores lasted at least four cycles, i.e. two months of subculture in CE conditions.

\section{Evaluation of the size of uredinia}

The size of uredinia was measured using the subset of internationally recognized standard geno- 
Table 1

The characterization of studied plant materials and localization of experiment sites

\begin{tabular}{|c|c|c|c|c|c|c|}
\hline \multirow{2}{*}{ No. } & \multirow{2}{*}{$\begin{array}{l}\text { Name of } \\
\text { genotype }\end{array}$} & \multirow{2}{*}{ Species/hybrid } & \multirow{2}{*}{ Description } & \multicolumn{3}{|c|}{ Experiment site $*$} \\
\hline & & & & Poznań & Marzęcin & Bałdy \\
\hline 1 & Piaskówka & \multirow{9}{*}{ Salix viminalis } & \multirow{2}{*}{ Polish landraces } & + & - & - \\
\hline 2 & Gigantea & & & + & - & - \\
\hline 3 & Rupp & & \multirow{4}{*}{ Swedish cultivars } & + & - & - \\
\hline 4 & Orm & & & + & - & - \\
\hline 5 & Ulv & & & + & + & - \\
\hline 6 & Jorr & & & - & + & - \\
\hline 7 & Start & & \multirow{3}{*}{ Polish cultivars } & - & - & + \\
\hline 8 & Sprint & & & - & - & + \\
\hline 9 & Turbo & & & - & - & + \\
\hline 10 & PZ 14 & \multirow{5}{*}{$\begin{array}{c}\text { Salix viminalis } x \text { Populus } \\
\text { tremula }\end{array}$} & \multirow{5}{*}{$\begin{array}{l}\text { putative hybrid with } \\
\text { trembling aspen }\end{array}$} & + & - & + \\
\hline 11 & PZ 21 & & & + & - & + \\
\hline 12 & PZ 29 & & & + & - & + \\
\hline 13 & PZ 41 & & & + & - & + \\
\hline 14 & PZ 42 & & & + & - & + \\
\hline 15 & PZ 40 & $\begin{array}{c}\text { Salix viminalis } \\
\mathrm{x} \text { Populus simonii }\end{array}$ & $\begin{array}{l}\text { putative hybrid with } \\
\text { Simon's poplar }\end{array}$ & + & - & + \\
\hline
\end{tabular}

* presence of the genotype is marked with "+" and absence is marked with "-_"

types, including two common osier cultivars (Jorr and Mullatin) and two willow hybrids: S. viminalis $\mathrm{x}$ S. schwerinii cv. Beagle and S. aurita x viminalis $x$ caprea var. Stipularis. Uredinia used for the measurement were obtained on young and fresh leaves of the above mentioned genotypes, after spraying them with a suspension of urediniospores. The concentration of spores used for inoculation was each time adjusted to 2 x $10^{5}$ urediniospores per $1 \mathrm{ml}$ of sterile distilled water (Pei et al. 1996). Each time the viability of spores was checked after 24 hours inoculation at $15^{\circ} \mathrm{C}$, in 60 $\mathrm{mm}$ Petrie dishes on 5\% water technical agar medium. The experiment was repeated if the germination of urediniospores was less than $60 \%$. Leaf inoculation was done using $95 \mathrm{~mm}^{2}$ leaf discs freshly cut from tested cultivars and placed with the abaxial side up, on 1,5 $\mathrm{cm}$ wide and $4 \mathrm{~cm}$ long stripes, prepared from Whatmann 3MM filter paper and formed in the shape of a bridge. Paper stripes supporting leaf discs were placed in 25-well plastic square boxes (Sterilin Ltd., Caerphilly, UK) and then soaked with sterile distilled water, applied by a laboratory sprayer, carefully avoiding moistening of tested willow leaves. The measurement of the size of uredinia was done with Sigma Scan Pro computer software, version 5 (Systat Software Inc., Chicago, USA). The data were subjected to statistical calculations of variance analysis, using Statistica Package version 9 (StatSoft Polska).

\section{Evaluation of the morphology of urediniospores}

The morphology of urediniospores was checked on freshly propagated materials, obtained from the spores stored at $-20^{\circ} \mathrm{C}$. The spores were placed on specimen stubs covered with double sided adhesive tapes and sprayed with gold particles $(99,9 \%)$ in sputter coater Bal-Tec SCD050 (Balzers, Lichtenstein). The spores were photographed using Scanning Electron Microscope (SEM) Zeiss EVO40 (Carl Zeiss AG, Oberkochen, Germany). Each time two longest measurements were taken at right angles. The mean size of urediniospores was a result of 10 measurements.

\section{RESULTS}

Uredinia of rust were formed on all tested genotypes of willow, including two common osier cultivars and two hybrids with the other willow species. They were always produced on the abaxial leaf side (Figs $1-4)$. The color was bright yellow with little variation of its shading and intensity. At the propagation cycles the number of uredinia was usually between 250 and 2500 per leaf. The highest yields were obtained on cv. Stipularis.

On average the smallest uredinia were produced on the Swedish cultivar Jorr; the mean diameter of a uredinium formed at the abaxial side of leaves of this 

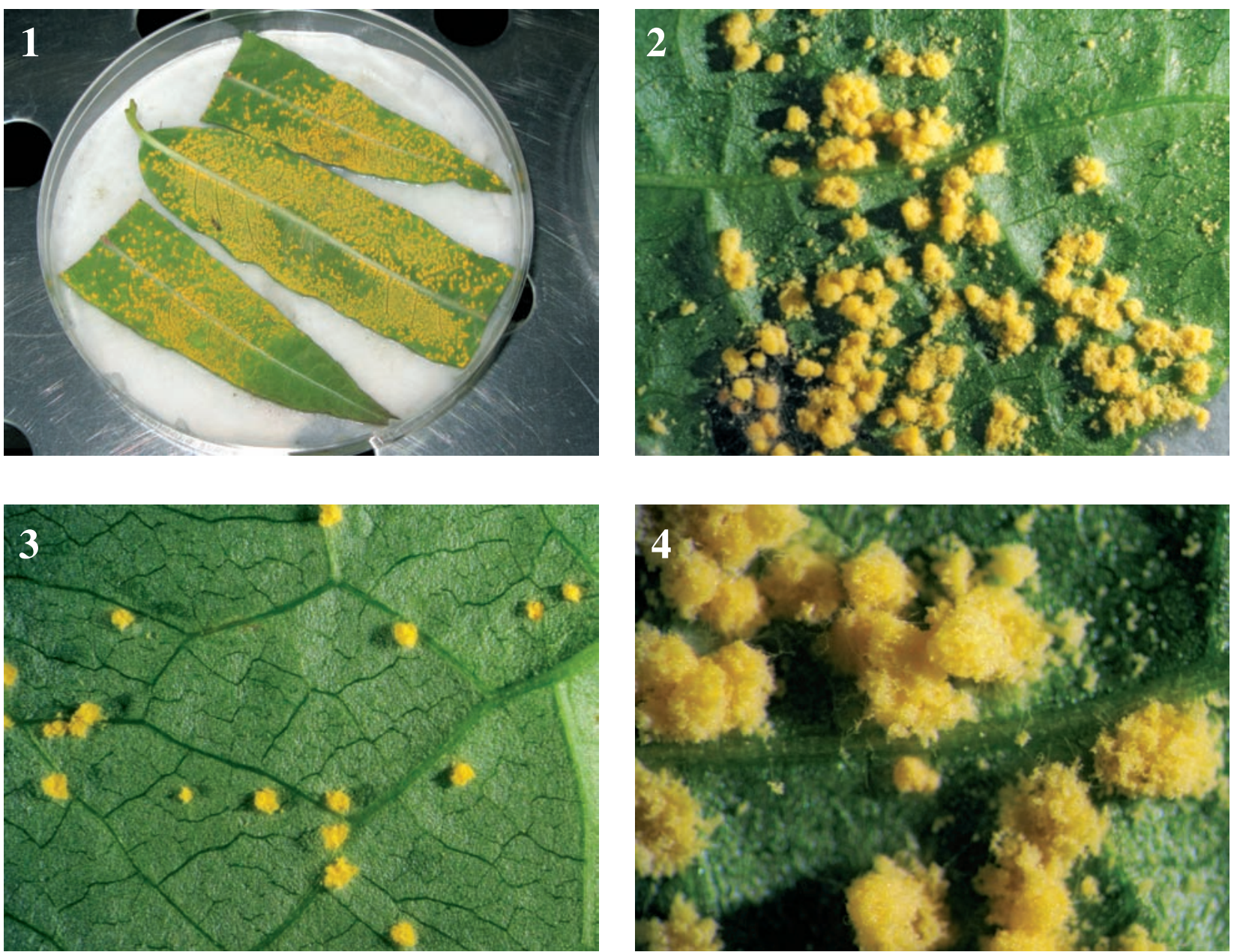

Figs 1-4. Uredinia of Melampsora larici-epitea on willow leaves (Salix spp.), Figs 2, 3-x 25; Fig. 4 - x 56

cultivar was $0.99 \mathrm{~mm}$ and varied from 0.89 to $1.17 \mathrm{~mm}$ (Table 2). The uredinia formed on cultivar Mullatin were also rather small $-1.11 \mathrm{~mm}$ on average, with size variation between 0.98 and $1.20 \mathrm{~mm}$. Uredinia formed on the hybrids between common osier and other willow species were bigger. They were 1.17 and $1.24 \mathrm{~mm}$ diameter, respectively for the cultivar Beagle ( $S$. viminalis x S. schwerinii) and cv. Stipularis (S. aurita $\mathrm{x}$ viminalis $\mathrm{x}$ caprea). The respective ranges of uredinia diameters were 1.07-1.24 $\mathrm{mm}$ and $1.17-1.31 \mathrm{~mm}$. On average the mean uredinium size was $1.13 \mathrm{~mm}$, with variation between 0.89 and $1.31 \mathrm{~mm}$. There were no differences between the mean diameters of uredinia produced by isolates obtained from common osier willow and its putative hybrids with poplars.

The mean diameter or a urediniospore was $11.52 \mu \mathrm{m}$ and ranged from 9.79 to $13.16 \mu \mathrm{m}$. The spores were usually ovoid or globoid (Figs 5-8). Some urediniospores were angular, when too dry, old or changed by the SEM photography preparation 
process. The spores were 9.79 to $11.47 \mu \mathrm{m}$ wide and 11.79 to $13.16 \mu \mathrm{m}$ long (Table 2). The average spore was $10.48 \times 12.41 \mu \mathrm{m}$. The typical spore of a fungal isolate obtained from common osier willow was 10.40 $\mathrm{x} 12.50 \mu \mathrm{m}$. The spores of the isolates obtained from putative hybrids were slightly less ovoid, with mean width of $10.60 \mu \mathrm{m}$ and mean length of $12.28 \mu \mathrm{m}$. All spores were spiny, spiky and evenly echinulated on the whole surface (Figs 5-8).
The size of uredinia was negatively correlated with the size of urediniospores. In case of osier willow cultivars as well as its hybrid with $S$. schwerinii (cv. Beagle) the Pearson correlation coefficient ranged between -0.519 and -0.611 . In case of cv. Stipularis this correlation was smaller $(-0.223)$.

Table 2

The mean size of uredinia and urediniospores of Melampsora larici-epitea isolates obtained on leaves of different willow genotypes (Salix spp.)

\begin{tabular}{|c|c|c|c|c|c|c|c|}
\hline \multirow{3}{*}{ No. } & \multirow{3}{*}{ Genotype } & \multicolumn{4}{|c|}{ Mean size of uredinia (mm) } & \multirow{2}{*}{\multicolumn{2}{|c|}{$\begin{array}{c}\text { Mean diameter } \\
\text { of urediniospores }(\mu \mathrm{m})\end{array}$}} \\
\hline & & \multicolumn{2}{|c|}{ common osier } & \multicolumn{2}{|c|}{ willow hybrids } & & \\
\hline & & Jorr $^{1}$ & Mullatin $^{2}$ & Beagle $^{3}$ & Stipularis $^{4}$ & length & width \\
\hline 1 & Piaskówka & 0.90 & 1.14 & 1.21 & 1,28 & 12.20 & 10.09 \\
\hline 2 & Gigantea & 1.00 & 1.15 & 1.24 & 1.19 & 13.06 & 10.75 \\
\hline 3 & Rupp & 0.87 & 0.98 & 1.07 & 1.24 & 13.16 & 11.47 \\
\hline 4 & Orm & 0.96 & 1.12 & 1.19 & 1.31 & 13.05 & 10.26 \\
\hline 5 & Ulv & 0.86 & 0.98 & 1.07 & 1.28 & 12.45 & 10.18 \\
\hline 6 & Jorr & 1.14 & 1.19 & 1.19 & 1.17 & 12.52 & 10.55 \\
\hline 7 & Start & 0.99 & 1.18 & 1.19 & 1.18 & 11.79 & 9.93 \\
\hline 8 & Sprint & 1.05 & 1.07 & 1.22 & 1.30 & 12.21 & 9.79 \\
\hline 9 & Turbo & 1.17 & 1.18 & 1.19 & 1.17 & 12.03 & 10.57 \\
\hline 10 & PZ 14 & 0.97 & 1.15 & 1.21 & 1.31 & 12.26 & 10.52 \\
\hline 11 & PZ 21 & 0.93 & 1.08 & 1.12 & 1.28 & 12.16 & 10.55 \\
\hline 12 & PZ 29 & 1.11 & 1.12 & 1.19 & 1.17 & 11.83 & 10.20 \\
\hline 13 & PZ 41 & 0.89 & 0.99 & 1.09 & 1.22 & 12.66 & 11.46 \\
\hline 14 & PZ 42 & 0.92 & 1.08 & 1.08 & 1.18 & 12.79 & 10.80 \\
\hline 15 & PZ 40 & 1.08 & 1.20 & 1.23 & 1.27 & 11.97 & 10.07 \\
\hline \multirow{3}{*}{ 总 } & mean & 0.99 & 1.11 & 1.17 & 1.24 & 12.50 & 10.40 \\
\hline & the smallest & 0.86 & 0.98 & 1.07 & 1.17 & 11.79 & 9.79 \\
\hline & the biggest & 1.17 & 1.19 & 1.24 & 1.31 & 13.16 & 11.47 \\
\hline \multirow{3}{*}{ 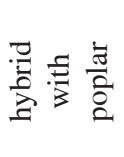 } & mean & 0.98 & 1.10 & 1.15 & 1.24 & 12.28 & 10.60 \\
\hline & the smallest & 0.89 & 0.99 & 1.09 & 1.17 & 11.83 & 10.07 \\
\hline & the biggest & 1.11 & 1.2 & 1.23 & 1.31 & 12.79 & 11.46 \\
\hline
\end{tabular}

S. viminalis

S. viminalix $\mathrm{x}$ viminalis

S. viminalis $\mathrm{x}$ schwerinii

S. aurita $\mathrm{x}$ viminalis $\mathrm{x}$ caprea

urediniospores were produced in controlled environment at $16 / 8$ photoperiod and constant temperature of $16^{\circ} \mathrm{C}$ on the willow hybrid S. aurita $x$ viminalis x caprea cv. Stipularis 

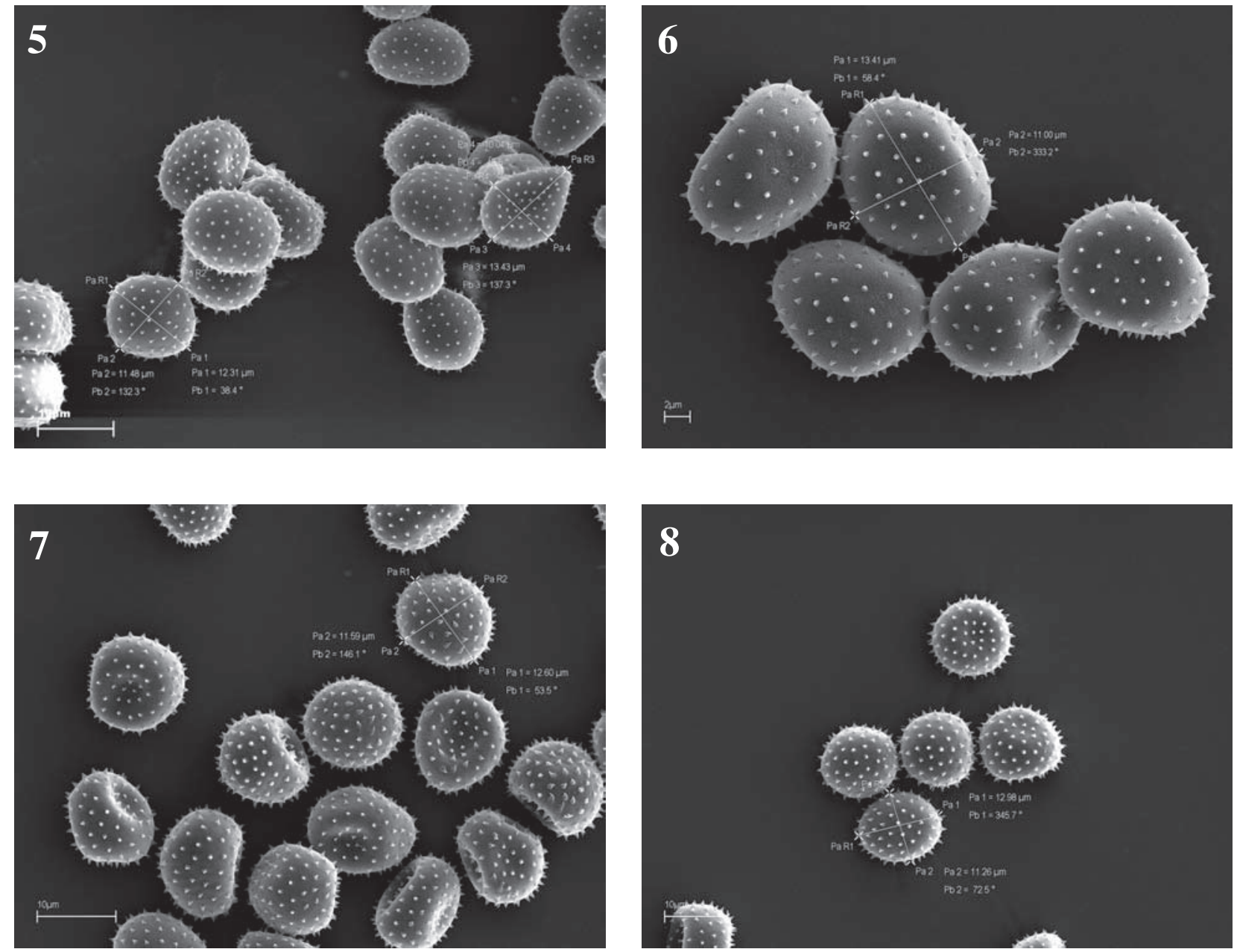

Figs 5-8. SEM photographs of urediniospores of Melampsora larici-epitea; isolates obtained from: 5 - S. viminalis cv. Orm, 6 - S. viminalis cv. Sprint, 7 - hybrid $S$. viminalis x $P$. tremula, 8 - hybrid $S$. viminalis x $P$. simonii, Figs $5,7,8$; scale bar $=10 \mu \mathrm{m}$, Fig. 6 scale bar $=2 \mu \mathrm{m}$

\section{DISCUSSION}

All isolates studied in this experiment produced bright yellow uredinia. They were formed only on abaxial leaf side. There was slight variation between the size of uredinia $(0.89-1.31 \mathrm{~mm})$ with the average of $1.13 \mathrm{~mm}$. Such size and location of uredinia is typical for M. larici-epitea. According to the data shown by P e i (2005) the position of uredinia of this species is hypophyllous and the size range varies from 0.25 to $1.5 \mathrm{~mm}$. The identical range of uredinia size of this species was also presented by B a g y a n a r a y a $\mathrm{n}$ a (2005). Uredinia formed by M. ribesii-viminalis are much smaller; their typical diameter is $0.25 \mathrm{~mm}$. It is very difficult to identify the alternate host of a rust species, and in such case the indirect character linked to this property is in demand. The result of this work suggests that the alternate host of the studied isolates is larch (Larix spp.), both in case of the isolates obtained from common osier and its hybrids with poplars. No significant differences were found between the isolates from both plant sources and the variation in uredinia size was nearly identical for both groups.

The size of uredinia of M. larici-epitea is bigger than of $M$. ribesii-viminalis, but the spore size is reversed - bigger for the latter species. According to $\mathrm{Pe}$ i (2005), the range of urediniospore size for the common osier rust species alternating on current varies from 14 to $19 \mu \mathrm{m}$, and according to $\mathrm{B}$ a g y a $\mathrm{n}$ a r a y a $n$ a (2005) the typical length of an urediniospore can reach $22 \mu \mathrm{m}$. In the present study the mean urediniospore size was $10.48 \times 12.41 \mu \mathrm{m}$, and the measurements ranged from 9.79 to $13.16 \mu \mathrm{m}$. Such spore sizes are typical for M. epitea f. sp. larici-epitea typica also referred to as M. larici-epitea f. typica. Hence, the size of urediniospores was an additional proof the isolates in study were willow rusts alternating on larch. 
Evenly echinulated surface of urediniospores allowed to exclude one more potential rust candidate species - M. larici-populina, commonly found on $P$. simonii. Urediniospores of this pathogen are smooth at the apex and much bigger that these found on common osier. Their size may reach as much as $50 \mu \mathrm{m}$ (Pei and Shang, 2005). Obviously this species is not expected on common osier, but it could attack its hybrid with Simon's poplar. However, this situation was not observed on the studied plant material. In turn, the hybrids of common osier with trembling aspen could result in the susceptibility of hybrids to M. larici-tremulae. Urediniospores of this species are also spiky and echinulated evenly on the whole surface of the spore. In this case however the uredinia are smaller $(0,5 \mathrm{~mm})$ and the urediniospores are bigger (up to $22 \mu \mathrm{m})$ than the observed ones.

There were no uredinia or urediniospore groups on the stems of tested willows, what suggested that a stem infecting form could be also excluded from this consideration.

The first uredinia to be produced in the pathogen's life cycle develop on mycelium resulting from the germination of aeciospores. Uredinia are produced on a dikaryotic mycelium, and the urediniospores also produce dikaryotic mycelium when they germinate (Cummins and Hiratsuka, 2003). The mycelium resulting from the germination of urediniospores usually produces more uredinia and this character was used to obtain genetically identical urediniospores for the present study. The most efficient propagation was obtained on a hybrid of common osier with two other willow species ( $S$. aurita $\mathrm{x}$ viminalis $\mathrm{x}$ caprea var. Stipularis). The effectiveness of this process was most probably a result of the correlation between bigger uredinia and numerous small urediniospores produced by rust isolates on this genotype. Out of four standards used in our study, cv. Stipularis proved to be the most effective, probably also due to its production of much broader and longer leaves than traditional common osier genotypes.

There were no thorough studies of willow rust and its causal pathogens in Poland by now. Our work ensured proper taxonomical classification of the rust fungi. Moreover, the studies were also done using unique plant materials of putative hybrids between willows and poplars. The first cytological analyses of these intergeneric crosses showed numerous abnormalities of hybrid embryos, what indirectly proved the success in creating hybrids between these two major genera of Salicaceae (B a g n i e w s ka-Zadworna et al. 2010). These plant materials are currently subjected to molecular studies, that can directly visualise the genetic content of the offspring resulting from the interbreeding between these two related taxa. Whatever is the result of launching such hybrid production, it is already shown that the studied materials are susceptible to willow rust caused by $M$. larici-epitea.

\section{CONCLUSIONS}

1. The size and morphology of uredinia and urediniospores of rust isolates obtained from common osier grown in different parts of Poland was typical for Melampsora larici-epitea $\mathrm{f}$. typica.

2. No significant differences were found between the rust isolates obtained from common osier and its putative hybrids with trembling aspen and Simon's poplar.

3. The hybrid of $S$. aurita $x$ viminalis $x$ caprea var. Stipularis allows a very efficient propagation of common osier rust.

\section{Acknowledgments}

The authors greatly acknowledge Lidia Orwińska - the owner of the Selo Energia Ltd. agricultural farm in Marzęcin and Stefan Szczukowski - the professor in Department of Plant Breeding and Seed Production at the University of Warmia and Mazury in Olsztyn for providing plant materials used in this experiment. SEM photographs were taken at the Department of Electron and Confocal Microscopy, Faculty of Biology, Adam Mickiewicz University of Poznań. Special thanks are also directed to Ming Hao Pei and Carmen Ruiz from Rothamsted Research, Harpenden, UK for sharing with standard genotypes of common osier and its hybrids, used for pathotyping and the assessment of the size of uredinia.

\section{REFERENCES}

Argu s G. W., 1997. Infrageneric classification of Salix (Salicaceae) in the New World. Systematic Botany Monographs, vol. 52. The American Society of Plant Taxonomists, Michigan.

Bagniewska-Zadworna A., Wojciechowicz M. K., Zenkteler M., Jeżowski S., Zenkteler E., 2010. Cytological analysis of hybrid embryos of intergeneric crosses between Salix viminalis and Populus species. Aust. J. Bot. 58: 42-48.

Bagy anarayana G., 2005. The species of Melampsora on Salix (Salicaceae). In: Rust diseases of willow and poplar. Eds. Ming Hao Pei and Alistair R. McCracken. CAB International. ISBN 0-85199-999-9, Wallingford, UK and Cambridge, MA, USA.

Cummins G. B., Hir at suka Y., 2003. Illustrated genera of rust fungi. $3^{\text {rd }}$ edn. APS Press, St. Paul, MN.

Gäumann E., 1959. Die Rostplize Mitteleuropas. Beiträge zur Kryptogamenflora Schweiz 12, Buchdruckerei Büchler and Co., Bern, Germany. 
Joanna Ciszewska-Marciniak, Małgorzata Jędryczka, Stanisław Jeżowski,

Hunter T., Peacock L., Turner H., Brain P., 2002. Effect of plantation design on stem infecting form of rust in willow biomass coppice. For. Path. 32: 87-97.

Jędryczka M., Ciszewska-Marciniak J., Przyb orowski J., 2008. The search for genetic sources of willow resistance to rust (Melampsora epitea Thüme). Phytopathologia Polonica, 49: 5-19.

Ke ole i a n G. A., Volk T. A., 2005. Renewable energy from willow biomass crops: life cycle energy, environmental and economic performance. Crit. Rev. Plant Sci. 24: 385-406.

Mc Cracken A. R., Daw son W. M., Bowden G., 2001. Yield responses of willow (Salix) grown in mixtures in short rotation coppice (SRC). Biomass and Bioenergy, 21: 311-319.

Mc Cracken A. R., Daw son W. M., 2003. Rust disease (Melampsora epitea) of willow (Salix spp.) grown as short rotation coppice (SRC) in inter- and intra-species mixtures. Ann. Appl. Biol. 143: 381-393.

Leppik E. E., 1972. Evolutionary specialization of rust fungi (Uredinales) in the Leguminoaceae. Annales Botanici Fennici, 9: 135-148.

Parker S. R., Royle D. J., Hunter T., 1993. Impact if Melampsora rust on yield of biomass willows. In: Proceedings of the $6^{\text {th }}$ International Congress of Plant Pathology, Montreal, Canada, 28 July - 6 August 1993. Ottawa, Canada.

Pei M. H., 2005. A brief review of Melampsora rusts on Salix. In: Rust diseases of willow and poplar. Eds. Ming Hao Pei and Alistair R. McCracken. CAB International. ISBN 0-85199-999-9, Wallingford, UK and Cambridge, MA, USA.

Pei M. H., Hunter T., Ruiz C., 1999. Occurrence of Melampsora rusts in biomass willow plantations for renewable energy in the United Kingdom, 17: 153-163.

Pei M. H., Royle D. J., Hunter T., 1995. A comparative study of stem-infecting and leaf-infecting forms of Melampsora rust on Salix viminalis in the UK. Mycol. Res. 99: 357-363.

Pei M. H., Royle D. J., Hunter T., 1996. Pathogenic specialization in Melampsora epitea var. epitea on Salix. Plant Pathology, 45: 679-690.

Pei M. H., Sh ang Y.Z., 2005. A brief summary of Melampsora species on Populus. [In:] (eds), Ming Hao Pei and Alistair R. McCracken, Rust diseases of willow and poplar. CAB International. ISBN 0-85199-999-9, Wallingford, UK and Cambridge, MA, USA.

Pei M. H., Ruiz C., Bayon C., Hunter T., 2004. Rust resistance in Salix to Melampsora larici-epitea. Plant Pathology, 53: 770-779.

Przyborowski J. A., Sulima P., 2010. The analysis of genetic diversity of Salix viminalis genotypes as a potential source of biomass by RAPD markers. Industrial Crops and Products, 31: 395-400.

R a m s te d t M., 1999. Rust disease on willows - virulence variation and resistance breeding strategies. Forest Ecology and Management, 121: 101-111.
Rönnberg-Wästljung A. C., S a mils B., Tsarouhas V., Gullberg U., 2008. Resistance to Melampsora larici-epitea leaf rust in Salix: analyses of quantitative trait loci. J. Appl. Gen. 49 (4): 321-331.

Samils B., 2005. Genetic structure of Melampsora larici-epitea populations in north-western Europe. In: Rust diseases of willow and poplar. Eds. Ming Hao Pei and Alistair R. McCracken. CAB International. ISBN 0-85199-999-9, Wallingford, UK and Cambridge, MA, USA.

Samils B., Mc Cracken A. R., Dawson W. M., Gu11berg U., 2003. Host-specific genetic composition of Melampsora larici-epitea populations on two Salix viminalis varieties in a mixture trial. Eur. J. Plant Pathol. 109: 183-190.

Samils B., Lagercrantz U., Lascoux M., Gulberg U., 2001. Genetic structure of Melampsora epitea populations in Swedish Salix viminalis plantations. Eur. J. Plant Pathol. 107: 399-409.

S avile D. B. O., 1976. Evolution of the rust fungi (Uredinales) as reflected by their ecological problems. Evolutionary Biology, 9: 137-207.

Szczukowski S., Stolarski M., Tworkowsk I. J., Przyborowski J., K 1 a s a A., 2005. Productivity of willow coppice plants grown in short rotations. Plant Soil Environ. 51 (9): 423-430.

Wi 1 s on M., He nder s on D. M., 1966. The British rust fungi. Cambridge University Press, Cambridge, UK.

Zenkteler M.,Wojciechowicz K.,B a g n iewska-Zadworna A., Zenkteler E., Jeżowski S., 2005. Intergeneric crossability studies on obtaining hybrids between Salix viminalis and four Populus species. Trees, 19: 638-643.

\section{Morfologia urediniów i urediniospor grzyba Melampsora larici-epitea Kleb. - groźnego patogena wierzby wiciowej (Salix viminalis L.) w Polsce}

\section{Streszczenie}

Rdza (Melampsora spp.) jest groźną chorobą wielu gatunków wierzb (Salix spp.), w tym wierzby wiciowej (Salix viminalis). W obrębie rodzaju Melampsora występują liczne gatunki, rasy oraz formy specjalne, zdolne do infekowania różnych gatunków i genotypów wierzby. Dotychczas w Europie rozpoznano dwa gatunki rdzy porażającej wierzbę wiciową: M. larici-epitea Kleb. oraz M. ribesii-viminalis Kleb. Ponadto stwierdzono występowanie formy infekującej łodygi wierzby (ang. SIF - stem infecting form), charakteryzującej się brakiem fazy generatywnej w cyklu życiowym. Celem niniejszej pracy była identyfikacja gatunków grzybów rodzaju Melampsora powodujących rdzę wierzby wiciowej w Polsce. Materiał badawczy stanowiły izolaty zebrane z 15 różnych genotypów 
wierzby, w tym z 4 szwedzkich i 3 polskich odmian, 2 populacji miejscowych oraz 6 potencjalnych mieszańców Salix x Populus. Próby liści wierzby z objawami rdzy zbierano przez trzy kolejne lata (2008 - 2010) w trzech regionach Polski: w Wielkopolsce, na Ziemi Lubuskiej oraz Warmii. W każdym przypadku objawy choroby stwierdzano wyłącznie na dolnej stronie liści. Wielkość urediniów oznaczono programem Sigma Scan Pro badając efekty inokulacji czterech genotypów wierzby, w tym dwóch odmian wierzby wiciowej i dwóch mieszańców międzygatunkowych. Wszystkie izolaty grzybów Melampsora spp., zastosowane w testach inokulacyjnych, uzyskano z pojedynczych urediniów, co powodowało, iż były identyczne pod względem genetycznym.

Przeprowadzone badania potwierdziły, że patogenem odpowiedzialnym za rdzę wierzby wiciowej w Polsce jest gatunek M. larici-epitea f. typica. Średnice urediniów oraz wymiary i morfologia urediniospor były podobne w przypadku wszystkich izolatów, także pochodzących z potencjalnych roślin mieszańcowych Salix x Populus. Średnia wielkość uredinium wynosiła 1,1 mm; dla poszczególnych izolatów zróżnicowanie było niewielkie (od 0,9 do 1,3 mm) i zależało od genotypu wierzby, jakości materiału roślinnego użytego do inokulacji oraz warunków infekcji. Średni wymiar urediniospor wynosił 12,4 x $10,5 \mu \mathrm{m}$ i wahał się w granicach $9,8-13,2 \mu \mathrm{m}$. Urediniospory z wierzby wiciowej były nieznacznie większe i bardziej owalne $(12,5$ $\mathrm{x} 10,4 \mu \mathrm{m}) \mathrm{w}$ porównaniu do zarodników uzyskanych z izolatów pochodzących z domniemanych mieszańców międzyrodzajowych Salix x Populus (12,3 x 10,6 $\mu \mathrm{m})$, jednakże różnice pomiędzy nimi nie były istotne statystycznie. Urediniospory miały kształt owalny, jajowaty lub nieregularny a ich powierzchnia była całkowicie pokryta licznymi wypustkami. Wielkość urediniów oraz rozmiary i morfologia urediniospor całkowicie zgadzają się z danymi literaturowymi podawanymi dla $M$. larici-epitea f. typica. 
